\title{
Changeable cuttlefish camouflage is influenced by horizontal and vertical aspects of the visual background
}

\author{
Alexandra Barbosa • Leib Litman · Roger T. Hanlon
}

Published online: 26 February 2008

(C) Springer-Verlag 2008

\section{Erratum to: J Comp Physiol A}

\section{DOI 10.1007/s00359-007-0311-1}

The original version of this article unfortunately contained a mistake.

The article category must read "Original Paper", and the list of author names must read:

Alexandra Barbosa, Leib Litman, and Roger T. Hanlon

The online version of the original article can be found under doi:10.1007/s00359-007-0311-1.

\footnotetext{
A. Barbosa Institute of Biomedical Sciences Abel Salazar (ICBAS),

University of Porto, Porto, Portugal

A. Barbosa $(\bowtie) \cdot$ R. T. Hanlon

Marine Resources Center, Marine Biological Laboratory,

Woods Hole, MA, USA

e-mail: abarbosa@mbl.edu

L. Litman

Department of Psychology, New York University,

New York, NY, USA
} 